\title{
EKSTRAKSI SENYAWA TANIN DARI MANGROVE (Brugueria gymnorrhiza) MENGGUNAKAN PELARUT AQUADES DAN ETANOL SEBAGAI PEWARNA ALAMI DAN PENGUAT SERAT KAIN
}

Tika Meliyati Putri, Eko Malis, Rosyid Ridho

Fakultas Ilmu Pengetahuan dan Matematika, Universitas

PGRI Banyuwangi (UNIBA) Jln. Ikan Tongkol 22,

Banyuwangi 68416

E-mail: unibabwi.puslit@,gmail.com

\begin{abstract}
ABSTRAK
Tanin merupakan senyawa kompleks biasanya campuran polifenol tidak mengkristal (tannin extracts). Penelitian ini pengambilan ektrak tanin dengan metode ektraksi soklet selama 3 jam dengan pelarut aquades dan pencampuran aquades- etanol dengan pernabdingan $1: 1,1: 2,1: 3$, dan $1: 4$ dengan suhu pelarut aquades $70^{\circ} \mathrm{C}$ dan pencampuran aquades-etanol $80^{\circ} \mathrm{C}$. Pewarnaan ditambahkan $\mathrm{NaCl}$ dan proses mordanting dengan menggunakan $\mathrm{Al}_{2}\left(\mathrm{SO}_{4}\right)_{3}$. Ikatan yang terbentuk hanya merupakan ikatan hidrogen, tetapi zat fiksator $\left(\mathrm{Al}_{2}\left(\mathrm{SO}_{4}\right)_{3}, \mathrm{CaO}\right.$, dan $\mathrm{CaCO}_{3}$ dapat mengunci dan melapisi tanin agar tidak mudah keluar dari dalam serat. Hal ini dapat dilihat dari nilai uji ketahanan luntur warna terhadap pencucian pada yang memperoleh nilai rata-rata antara 4-5 CD dan nilai ratarata RGB bahwa nilai paling baik adalah hasil ekstrak dengan pelarut aquades-etanol perbandingan 1:3 dengan nilai rata-rata fiksasi $\mathrm{CaO} 0 \mathrm{CD}$ dan $\mathrm{CaCO}_{3}$ 6,6 CD. Hasil identifikasi terhadap isolat menggunakan spektrofotometer FTIR didapat spektrum yang spesifik untuk senyawa tanin yaitu pada bilangan gelombang $3424,96 \mathrm{~cm}^{-1} ; 2923,56 \mathrm{~cm}^{-}$ ; $1635,34 \mathrm{~cm}^{-1} ; 1130,08 \mathrm{~cm}^{-1}, 759,816 \mathrm{~cm}^{-1}$. Kekuatan serat yang baik adalah kain yang mendapatkan treatment $\mathrm{CaO}$ dan $\mathrm{CaCO}_{3}$ dengan nilai $3 \mathrm{Kg}$ dibanding dengan sampel kain yang mendapatkan treatment $\mathrm{Al} 2\left(\mathrm{SO}_{4}\right)_{3}$ dengan nilai $2,5 \mathrm{Kg}$.
\end{abstract}

Kata Kunci: Tanin, aquades, etanol, RGB, FTIR

\section{Pendahuluan}

Penggunaan ZPA telah Sumber daya nabati berupa tanaman yang dapat dimanfaatkan sebagai bahan tambahan makanan antara lain untuk bahan pewarna. Zatwarna alami yang banyak dipakai berasal dari berbagai bagian dari tumbuh tumbuhan. Namun demikian pemakaian zat warna alami di masa sekarang masih belum popular karena proses untuk memperoleh zat warna tersebut lebih sukar dibandingkan pembuatan zat warna sintetis. Sementara pemakaian zat warna alami lebih aman karena sisa pemakaiannya mudah diuraikan oleh bakteri dibandingkan zat warna sintetis

Mangrove mengandung alkaloid, saponin, flavonoid, tanin dan polifenol. Tanin memiliki aktivitas sebagai antijamur. Senyawa alkaloid berperan sebagai antimikroba dengan merusak dinding sel mikroba. Sedangkan flavonoid dapat merusak permeabilitas dinding sel mikroba mampu menghambat pertumbuhan mikroba. Senyawa saponin dari tumbuhan adalah glikosida dari steroid, yang larut dalam air dan mempunyai kemampuan membentuk buih sabun bila dikocok di air. Penggunaan saponin sebagai deterjen alam dan racun ikan telah 
dikenal oleh masyarakat tradisional. Ekstrak dan bahan mentah dari mangrove telah banyak dimanfaatkan oleh masyarakat pesisir untuk keperluan mencuci jarring dari kerak kotoran yang berasal dari air laut, hasil ekstrak mangrove berwarna coklat pekat yang dapat merubah warna jarring setelah mendapatkan perlakuan perendaman dan pencucian. Dari hasil yang didapatkan dapat lihat bahwa hasil ekstrak mangrove dapat dimanfaatkan sebagai zat pewarna alami dan tanin sebagai antijamur untuk pengawet serat kain.

Akan tetapi masyarakat lupa akan pentingnya ketahanan kualitas serat kain untuk menjaga ketahanan masa simpan tekstil. Bahan pewarna sintesis juga dapat mempengaruhi ketahanan kekuatan tarik pada kain karena bahan kimia yang terkandung didalamnya, sehingga mudah rapuh dan sobek. Alangkah baiknya jika bahan pewarna pewarna tekstil menggunakan bahan alam yang juga mengandung senyawa yang dapat mempertahankan kekuatan tarik pada serat kain, sehingga menghasilkan kain berkualitas tinggi.

Berdasarkan latar belakang masalah yang telah diuraikan diatas tidak menutup kemungkinan bahwa penambahan zat pewarna yang mengandung tanin. Untuk membuktikan hal tersebut maka peneliti melaksanakan penelitian dengan judul "Ekstraks itanin dari mangrove (bruguiera gymnorrhiza) menggunakaan pelarut etanol dan aquades sebagai pewarna alami dan penguat serat kain."

\section{Metode Penelitian}

\section{Bahan dan Alat}

Bahan yang digunakan dalam penelitian ini adalah Bubuk Batang Mangrove, Nacl, Aquades, Etanol 70\%, Tawas, $\mathrm{CaO}, \mathrm{CaCO}_{3}$, Detergen.

Erlenmeyer, Glass beaker, Corong, Pipet Ukur, Pipet tetes, Thermometer, Kaca arloji, Kertas saring, Neraca analitik, Alat sokletasi, Alat sensor RGB Tipe tcs230, Alat Uji Tarik.

\section{Metode penelitian}

\section{Tahap Preparasi Batang mangrove}

Batang mangrove dengan kualitas baik dijemur di bawah sinar matahari selama 2 hari. Batang mangrove kemudian dioven hingga kering dan dihaluskan. Selanjutnya batang diekstraksi dengan metode sokletasi.

\section{Tahap Ekstraksi}

Pada proses ekstraksi, batang mangrove yang telah dihaluskan ditimbang sebanyak 20 gram. Sampel selanjutnya dimasukan dalam ekstraktor. Sampel diekstraksi menggunakan pelarut sesuai dengan perlakuan jenis pelarut yaitu menggunakan aqeades, aquades dan etanol 
dengan perbandingan 1:1, 1:2, 1:3, 1:4 masing-masing sebanyak $200 \mathrm{~mL}$ selama 3 jam. Suhu ekstraksi disesuaikan dengan titik didih pelarut yaitu untuk aquades dan etanol 70\% sebesar $70^{\circ} \mathrm{C}$, aquades sebesar $100^{\circ} \mathrm{C}$.

\section{Tahap Mordanting}

Tawas dilarutkan dalam 1 liter air, panaskan sampai mendidih. Kain dimasukkan ke dalam larutan mordan yang sebelumnya dibasahi dengan air dan diaduk selama 1 jam.Api dimatikan dan didiamkan selama 1 jam. Diangkat dan di cuci bersih (tanpa sabun dan tambahan lainnya) keringkn dan setrika.

\section{Tahap Pewarnaan Kain}

Hasil ekstrasi dimasukkan pada glass beaker.Kemudian kain mori ukuran 15x15 kedalam larutan pewarna. Biarkan selama 60 menit. Kemudian tambahkan larutan Nacl 1M biarkan kembali selama 60 menit. Setelah mencapai 60 menit angkat dan tiriskan lalu dikeringkan. Ambil gambar gain yang sudah kering.

\section{Tahap Fiksasi}

Menimbang Tawas, $\mathrm{CaO}$, dan $\mathrm{CaCO}_{3}$ masing-masing 0,5 $\mathrm{M}$ untuk dilarutkan kedalam $100 \mathrm{~mL}$ air. Letakkan larutan kedalam baskom. Kain yang sudah diwarnai dan sudah dikeringkan masukkan kedalam larutan kapur selama 7,5 menit setelah itu cuci bersih dan keringkan.

\section{Evaluasi Ketahanan Luntur}

\section{Pengujian Ketahanan Luntur Warna terhadap Pencucian}

Kain dimasukkan. Proses pencucian dilakukan selama 45 menit. Diaduk dengan volume larutan $200 \mathrm{Ml}$ dan sabun $0,5 \%$ dari volume larutan. Setelah selesai dicuci, lalu tiap contoh uji dibilas dua kali dalam $100 \mathrm{ml}$ air selama masing-masing 1 menit, sambil diperas dengan tangan. Kain lalu diperas dengan mengel pemeras, kemudian dikeringkan.

\subsubsection{Pengujian Tahan Luntur Warna terhadap Gosokan}

Pengujian dilakukan 2 kali, yaitu gosokan dengan kain kering dan gosokan dengan kain basah. Kain dengan ukuran $15 \times 15 \mathrm{~cm}$. Pada pengujian digosokkan kain putih kering, lalu diulangi dengan kain putih basah. Penodaan dinilai dengan Staining Scale sedangkan kelunturan warna pada kain dinilai dengan Grey Scale.

\section{Pengujian Tahan Luntur Warna terhadap Panas Penyeterikaan Kering}

Kain diletakkan di atas sepotong kain kapas putih pada permukaan halus dan horizontal.Seterika tangan dengan suhu tertentu untuk jenis serat tertentu diletakkan di atas kain selama 10 detik. Kemudian dievaluasi perubahanwarna kain dengan membandingkannya terhadap grey scale. Sedangkan untuk penodaan warna caranya sama dengan cara diatas, kecuali kain ditutup dengan kain putih kering. Penodaan warna pada kain putih atas 
inidievaluasi dengan membandingkannya terhadap staining scale.

\section{Analisis RGB}

Dilakukan dengan menggunakan alat sensor warna tipe tcs250. Dengan mempersiapkan kalibrasi warna pada alat sensor warna, kemudian letakkan kain sampel yang sudah diwarnai pada sinar cahaya alat sensor dan dicatat nilai RGB.

\section{Analisis Fourier Transform Infra Red (FTIR)}

Dilakukan dengan memasukan sampel pada alat FTIR kemudian dialiri cahaya infra merah. Ikatan molekul kemudian menghasilkan vibrasi tertentu. Nilai vibrasi ini kemudianmembentuk spektrum. Untuk mengetahui gugus fungsi dalam sampel, spekrum ini harus diinterpretasi dengan tabel interpretasi FTIR. Hasil tersebut kemudian dicocokan dengan serapan spesifik tanin.

\section{Analisis uji kekuatan tarik}

Kain dipasang pada sepasang penjepit sedemikian rupa sehingga terletak di tengah-tengah dan tepi bawah kain segaris dengan dasar penjepit. Pada kedudukan ini, tepi atas kain akan sejajar dengan permukaan atas penjepit dan benang-benang yang sejajar lebar kain akan tegak lurus padanya. Kedua penjepit dirapatkan dengan memutar sekrup pengencang, sehingga tekanan jepitan kedua penjepit sama besar.

\section{HASIL DAN PEMBAHASAN}

\section{Tahap Preparasi Batang Mangrove}

Tahap preparasi batang untuk menghasilkan serbuk batang yang berkualitas baik dan mempermudah penumbukan batang harus di keringkan sangat kering sekali, Batang mangrove yang sudah di tumbuk akan berubah warna menjadi serbuk berwarna coklat.

\section{Tahap Ekstraksi}

Hasil dari ekstraksi dengan menggunakan pelarut aquades yaitu menghasilkan endapan dan warna larutan coklat tua, sedangkan hasil ekstraksi dengan menggunakan pelarut aquades-etanol 1:1, 1:2, 1:3, 1:4 tidak menghasilkan endapan sama sekali dan warna larutan lebih pekat dengan warna hitam.

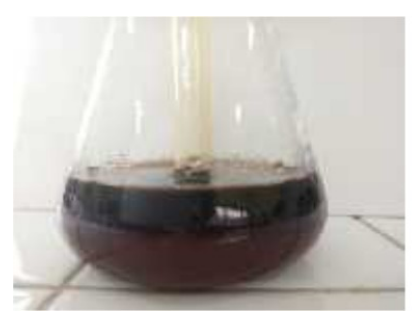

(A)

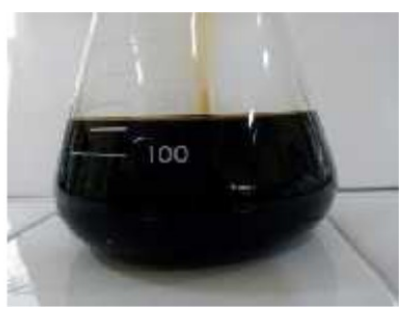

(B) 
Gambar 4.1 (A) hasil ekstraksi dengan pelarut aquades berwarna coklat dan menghasilkan endapan, (B) hasil ekstraksi dengan pelarut etanol-aquades dengan perbandingan 1:1, 1:2, 1:3, 1:4 berwarna hitam pekat

Pengendapan akan terjadi jika kosentrasi senyawa melebihi kelarutan. Pengendapan akan terjadi dengan cepat dari larutan jenuh. Pengendapan ada kaitannya dengan hasil kali kelarutan (Ksp). Dalam padatan, pengendapan terjadi karena kosentrasi tanin lebih dari kosentrasi pelarut.

\subsection{Tahap Mordanting}

Mordanting adalah tahap pertama proses pewarnaan dengan menggunakan tehnik pencelupan. Mordanting meningkatkan daya tarik zat warna alam terhadap bahan tekstil untuk menghasilkan kerataan dan ketajaman warna yang baik. Dari percobaan yang sudah dilakukan setelah proses moedanting dilakukan warna kain berubah menjadi agak putih keruh. Zat kimia yang yang digunakan adalah $\mathrm{Al}_{2}\left(\mathrm{SO}_{4}\right)_{3}$. Molekul permukaan mengalami gaya tarik resultan ke bawah dari dalam cairan, yang cenderung membuat area permukaan cairan sekecil mungkin.hal ini menyebabkan molekul dipermukaan yang akan ditarik ke dalam dan sehinggaselalu ada beberapa kekuatan ketidakseimbangan yang bekerja pada permukaan cairan.

\subsection{Tahap Pewarnaan Kain}

Dari percobaan yang sudah dilakukan warna kain yang dihasilkan adalah berbeda-beda. Untuk larutan hasil ekstraksi dengan nenggunakan aquades pewarnaaan kain menghasilkan warna coklat, sedangkan larutan yang menggunakan larutan aquades-etanol 1:1, 1:2, 1:3, 1:4 hasil kain berwarna coklat.Senyawa yang mengandung ion logam akan menghasilkan warna khas dari penelitian ektrak mangrove menghasilkan warna coklat karna memgandung Besi (III)

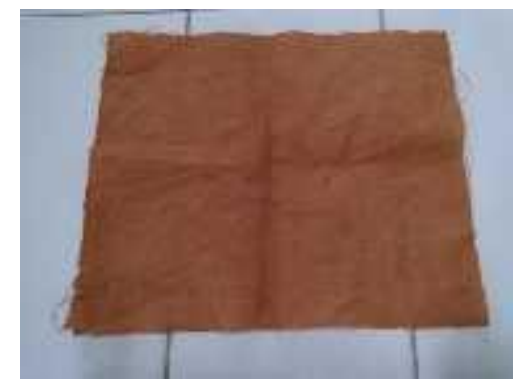

Gambar 4.2 Hasil pewarnaan ekstrak Mangrove

\section{Tahap Fiksasi}

Dari hasil percobaan yang sudah dilakukan semua kain yang sudah selesai tahap pewarnaan dilakukan tahap fiksasi, setelah tahap fiksasi kain akan berubah warna menjadi semakin pekat. Kain yang menggunakan fiksasi tawas mengasilkan warna kain yang tidak 
begitu pekat hanya mempertahankan warna aslinya. Kain yang menggunakan fiksasi $\mathrm{CaO}$ menghasilkan warna kain merah hati dan $\mathrm{CaCO} 3$ menghasilkan warna merah bata tua.

(A)

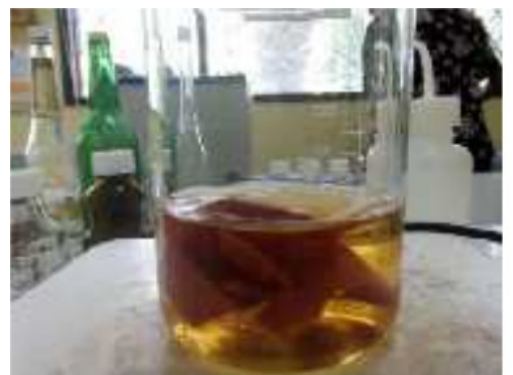

Gambar 4.3 (A) Proses Penambahan fiksasi selama 7 menit, (B) Hasil penambahan fiksasi setelah tahap pewarnaan

\section{Evaluasi Tahan Luntur}

Dari pengujian ketahanan luntur di ambil nilai sesuai dengan Spesifikasi kolorimetri yang tepat dari warna abu-abu standar dan perubahan warna pada Gray Scale, dapat dihitung dengan rumus nilai kokhromatikan Adam, dalam satuan C.D. (Color Difference).

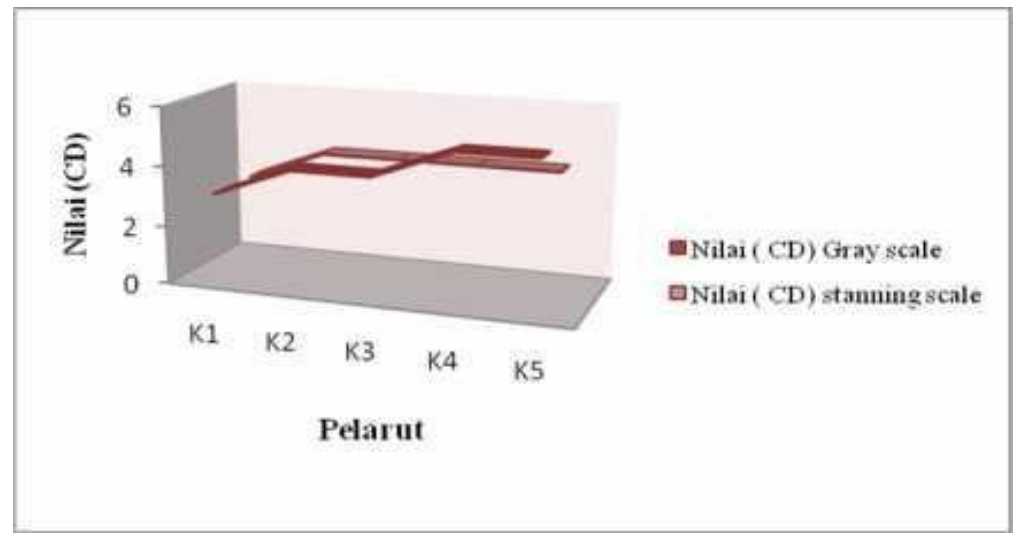

Gambar 4.4 Grafik nilai rata-rata evaluasi tahan luntur.

Warna pada kain hasil pewarnaan juga bersifat permanen. Hal ini dapat dilihat dari nilai uji ketahanan luntur warna terhadap pencucian pada yang memperoleh nilai rata-rata antara 4-5. Hal ini disebabkan pigmen pada mangrove (tanin) yang terkandung dalam larutan pewarna alam selama proses pewarnaan berlangsung dapat masuk kedalam serat dan bereaksi/berikatan dengan serat kapas (sellulosa). Walaupun ikatan yang terbentuk hanya merupakan ikatan hidrogen, tetapi zat fiksator $\left(\mathrm{Al}_{2}\left(\mathrm{SO}_{4}\right)_{3}, \mathrm{CaO}\right.$, dan $\mathrm{CaCO}_{3}$ dapat mengunci dan melapisi tanin agar tidak mudah keluar dari dalam serat. Hal ini akan menyebabkan tanin yang telah berikatan dengan serat tersebut tidak mudah lepas dari serat dan melunturi kain uji saat dilakukan uji ketahanan luntur warna terhadap pencucian sehingga 
diperoleh hasil pewarnaan mempunyai ketahanan luntur yang baik terhadap pencucian.

\section{Analisis RGB dengan Alat Sensor Warna Tipe tes230}

Dilakukan analisis untuk mendapatkan data kuantitatif dari evaluasi tahan luntur. Analisis RGB dilakukan dengan penambahan alat sensor Warna tipe tcs230 karena adanya pengaruh cahaya sensor yang diaktifkan supaya bisa menerangi objek atau sampel kain. Sebelum dilakukan uji sampel maka harus menentukan kalibrasi warna RGB bertujuan agar dapat mengetahui reng nilai sampel pada analisis RGB.

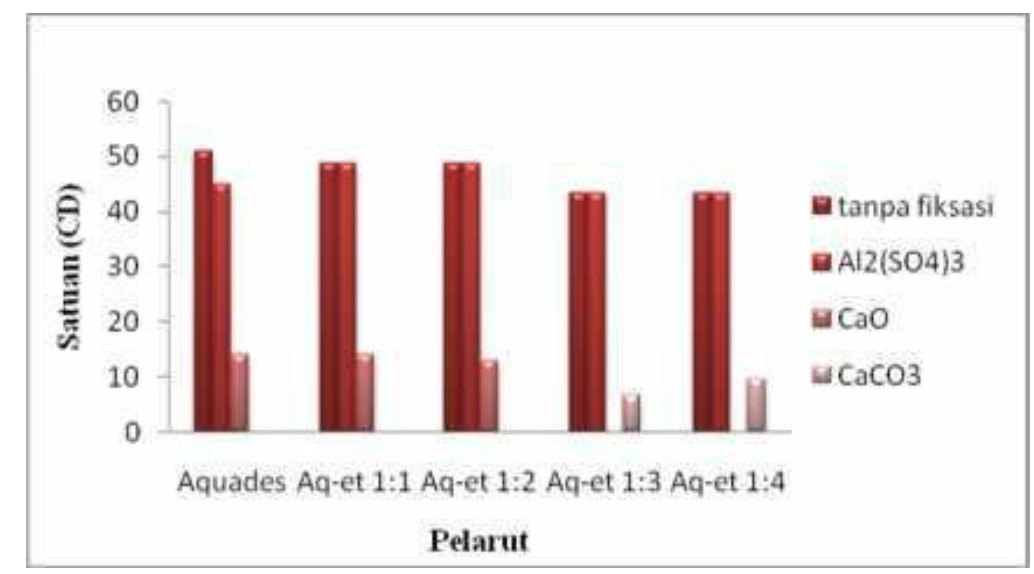

\section{Gambar 4.5 Nilai tahan luntur dengan analisis RGB}

Dapat diketahui dari nilai rata-rata RGB bahwa nilai paling baik adalah hasil ekstrak dengan pelarut aquades-etanol perbandingan 1:3 dengan nilai ratarata fiksasi $\mathrm{CaO} 0$ dan $\mathrm{CaCO}_{3}$ 6,6.

\subsection{Analisis Fourier Transform Infra Red (FTIR)}

Identifikasi dengan spektrofotometer FTIR dilakukan untuk mengetahui gugus fungsi yang terdapat dalam isolat. Hasil dari identifikasi terhadap isolat menggunakan spektrofotometer FTIR didapat beberapa spektrum bilangan gelombang yang identik dengan spektrum bilangan gelombang yang dimiliki tanin. Data perbandingan spektrum bilangan gelombang antara isolat dengan senyawa tanin dapat dilihat gambar 4.6. 


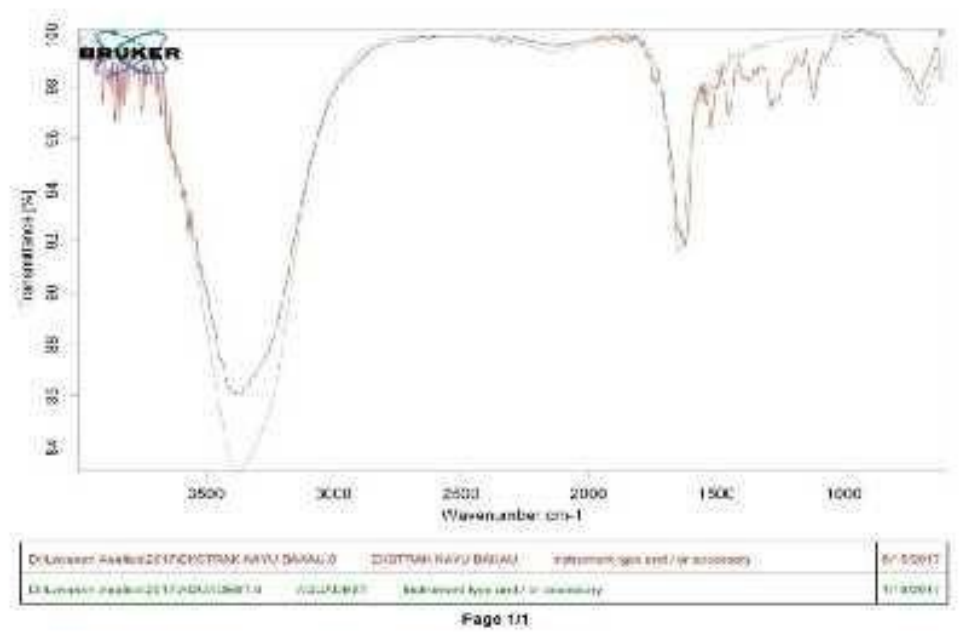

Gambar 4.6 transmitan dari hasil uji FTIR ekstrak tanin

Tabel 4.2 Bilangan gelombang

\begin{tabular}{|c|c|c|c|c|}
\hline \multirow[b]{2}{*}{ Puncak } & \multicolumn{3}{|c|}{ Bilangan gelombang $\left(\mathrm{cm}^{-1}\right)$} & \multirow[b]{2}{*}{ Jenis Vibrasi } \\
\hline & $\begin{array}{l}\text { Isolat } \\
\text { sampel }\end{array}$ & $\begin{array}{l}\text { Senyawa } \\
\text { tannin }\end{array}$ & Pustaka & \\
\hline 1 & 3424,96 & 3392,7 & $3500-3000$ & $\begin{array}{l}\text { Rentangan asimetri } \\
\mathrm{OH}\end{array}$ \\
\hline 2 & 2923,56 & 2932,1 & $3000-2900$ & Rentangan $\mathrm{CH} \mathrm{sp}^{3}$ \\
\hline \multirow[t]{3}{*}{3} & 1635,34 & \multirow{2}{*}{$\begin{array}{l}1515,4 \\
1448,1\end{array}$} & $1645-1615$ & $\begin{array}{l}\text { Rentang cicin } \\
\text { aromatic }\end{array}$ \\
\hline & & & . & \\
\hline & & 1404,0 & & \\
\hline 4 & - & 1263,7 & $1280-1220$ & $\begin{array}{l}\text { R-O-Ar (eter } \\
\text { aromatic) }\end{array}$ \\
\hline 5 & 1130,08 & 1058,7 & $1120-1080$ & $\begin{array}{l}\text { C-O alkohol } \\
\text { sekunder }\end{array}$ \\
\hline \multirow[t]{2}{*}{6} & - & \multirow[t]{2}{*}{833,8} & $900-420$ & $\begin{array}{l}\mathrm{C}-\mathrm{H} \text { out of place, } \mathrm{p}- \\
\text { subtitusi benzene }\end{array}$ \\
\hline & & & & \\
\hline & & 553,3 & & \\
\hline 7 & & 768,7 & $900-650$ & OH out of place;o- \\
\hline
\end{tabular}


Bilangan gelombang isolat yang identik dengan bilangan gelombang tanin diantaranya yaitu pada bilangan gelombang $3424,96 \mathrm{~cm}^{-1}$ yang menyatakan adanya rentang asimetri $\mathrm{OH}$, bilangan gelombang $2923,56 \mathrm{~cm}^{-1}$ yang menyatakan adanya rentang $\mathrm{CH}$ sp3, bilangan gelombang $1635,34 \mathrm{~cm}^{-1}$ yang menyatakan rentang cincin aromatik, bilangan gelombang $1130,08 \mathrm{~cm}^{-1}$ yang menyatakan adanya gugus C-O alkohol sekunder dan bilangan gelombang $759,816 \mathrm{~cm}^{-1}$ yang menyatakan adanya cincin aromatik yang tersubstitusi pada posisi orto. Puncak-puncak spesifik tersebut merupakan puncak spesifik dari senyawa tanin sehingga memperkuat dugaan bahwa isolat hasil ektraksi batang mangrove adalah senyawa tanin. sehingga memperkuat dugaan bahwa isolat hasil ektraksi mangrove adalah senyawa tanin. gelombang $333 \mathrm{~nm}$. Dengan penambahan pereaksi geser menguatkan dugaan bahwa isolat yang diperoleh adalah tanin yang tersubstitusi $\mathrm{OH}$ pada posisi orto di cincin A.

\subsection{Uji Kekuatan Tarik}

Dari hasil penelitian dapat diketahui bahwa mangrove dapat mewarnai serat kapas dengan warna coklat karena mangrove mengandung tanin. Tanin dapat diekstrak dengan menggunakan aquades dan etanol. Warna coklat dari tanin dapat mewarnai bahan kapas secara permanen. Reaksi antara serat kapas (sellulosa) dengan pigmen pada kain mangrove (tanin) dapat dilihat pada Gambar.

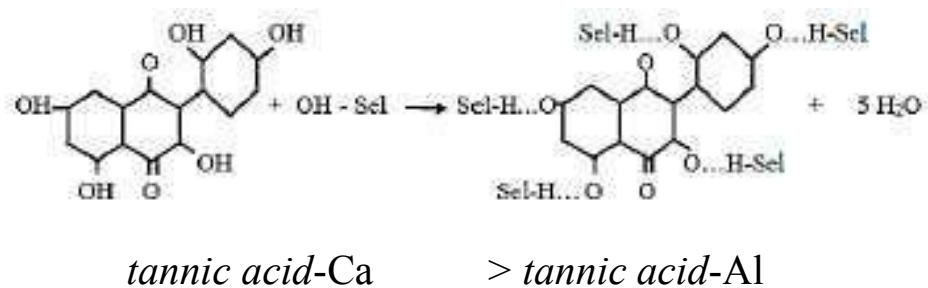

\section{Gambar 4.7 Ikatan yang terjadi antara serat sellulosa dan tanin}

Tanin bertindak seperti asam ringan berdasarkan banyak gugus-OH fenolik. Asam tanin adalah bentuk yang paling sederhana hydrolysable tanin. Salah satu sifat yang paling penting dari tanin dan asam tanin adalah kemampuannya untuk membentuk kompleks chelat dengan ion logam. Meskipun asam tanin dapat berfungsi sebagai agen antimikroba alami, tetapi tidak aktif terhadap spektrum yang luas dari jamur dan bakteri (Salunkhe et al. 1989; Sanderson et al. 2001).

Data yang didapatkan bahwa kain mori ditreatment membentuk asam tanin 
1.kompleks logam menunjukkan peningkatan sifat anti-mikroba dibandingkan dengan sampel yang diperlakukan dengan asam tanin atau ion logam secara terpisah dan pada konsentrasi yang sama. Hasil juga menunjukkan bahwa sifat antibakteri dan antijamur dari kain mori yang ditreatment dengan asam tanninkompleks logam.

Keawetan kain mori yang ditreatment dengan $\mathrm{CaO}$ dan $\mathrm{CaCO}_{3}$ sangat tinggi dibandingkan dengan keawetan kain mori yang ditreatment dengan $\mathrm{A} 12\left(\mathrm{SO}_{4}\right)_{3}$ pada tipe ion logam yang sama. Keawetan kain mori setelah ditreatment dengan asam tanin- kompleks logam tergantung pada jenis ion logam yang digunakan dalam complexation dengan urutan:

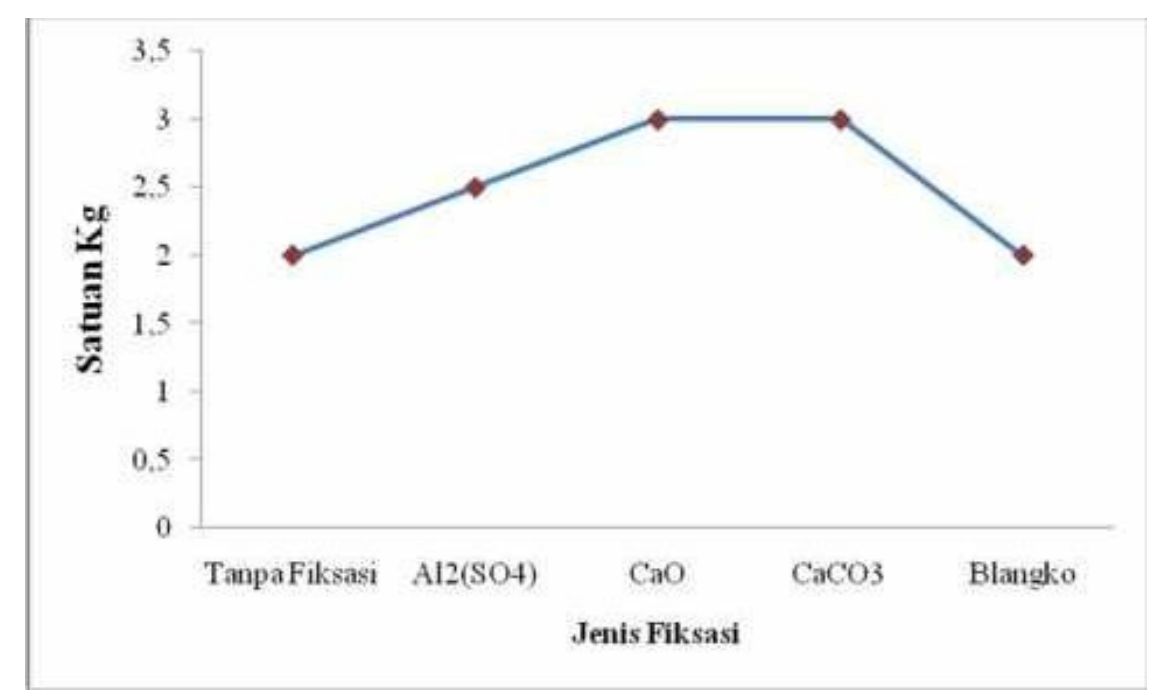

\section{Gambar 4.11 grafik nilai uji kuat tarik}

Dapat dilihat dari data grafik uji kuat tarik diketahi bahwa sampel kain yang yang mempunyai kekuatan serat yang baik adalah kain yang mendapatkan treatment $\mathrm{CaO}$ dan $\mathrm{CaCO}_{3}$ dengan nilai $3 \mathrm{Kg}$ dibanding dengan sampel kain yang mendapatkan treatment $\mathrm{A} 12\left(\mathrm{SO}_{4}\right)_{3}$ dengan nilai $2,5 \mathrm{Kg}$. Gaya tarik menarik antara rantai polimer memainkan peranan terhadap sifat polimer. Karena rantai polimer sangat panjang, gaya antar rantai menajdi berlipat ganda dibanding tarik menarik antar molekul biasa. Gugus samping yang berbeda dapat mengakibatkan polimer berikatan ion atau ikatan hidrogen pada rantai yang sama. Semakin kuat gaya akan berakibat pada naiknya kuat tarik. Gaya intermolekuler pada polimer dapat dipengaruhi oleh dipol pada unit monomer.

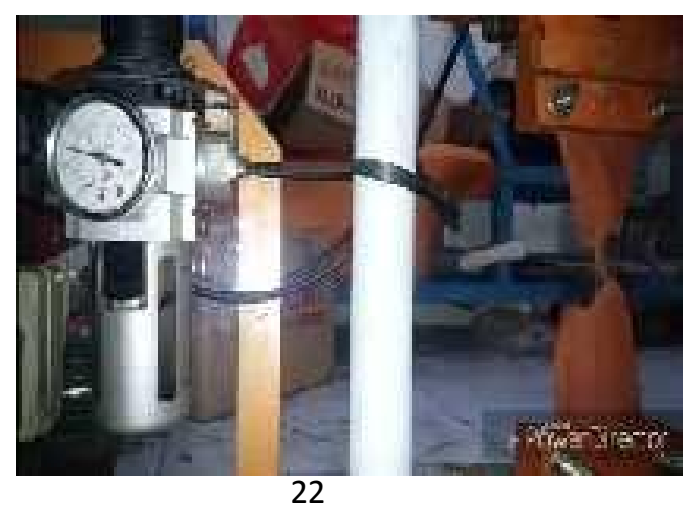




\section{Gambar 4.12 Proses Uji kuat tarik}

Dari hasil penelitian dan pembahasan di atas maka dapat disimpulkan bahwa :

1. Warna pada kain hasil pewarnaan juga bersifat permanen. Hal ini dapat dilihat dari nilai uji ketahanan luntur warna terhadap pencucian pada yang memperoleh nilai ratarata antara 4-5 CD dan nilai rata-rata RGB bahwa nilai paling baik adalah hasil ekstrak dengan pelarut aquades-etanol perbandingan 1:3 dengan nilai rata-rata fiksasi $\mathrm{CaO} 0$ dan $\mathrm{CaCO}_{3}$ 6,6.

2. Hasil identifikasi terhadap isolat menggunakan spektrofotometer FTIR didapat spektrum yang spesifik untuk senyawa tanin yaitu pada bilangan Kekuatan serat yang baik adalah kain yang mendapatkan treatment $\mathrm{CaO}$ dan $\mathrm{CaC}_{\mathrm{O} 3}$ dengan nilai $3 \mathrm{Kg}$ dibanding dengan sampel kain yang mendapatkan treatment $\mathrm{Al} 2\left(\mathrm{~S}_{\mathrm{O} 4) 3}\right.$ dengan nilai $2,5 \mathrm{Kg}$.

\section{Saran}

Perlu mengestimasi waktu dalam proses ektraksi agar tidak terlalu lama dalam proses esktraksi Perlu dilakukannya uji kadar logam agar dapat mengetahi layak pakai sebagai pewarna tekstil

\section{DAFTAR PUSTAKA}

Agati, G, Matteini, P, Goti, A, dan Tattini, M. 2007. Chloroplast located flavornoids can scavenge singlet oxygen. New Phytologist 174: 77-82.

Bandaranayake, W.M. 2002. Bioactivities, bioactive compounds and chemical constituents of mangrove plants. Wetlands Ecol. Manage 10: 421-452.

Banerjee, D., Chakrabarti. S., Hazra.A.K., Banerjee.S., Ray.J., dan Mukherjee, B. 2008. Antioxidant activity and total phenolics of some mangroves in Sundarbans. African Journal of Biotechnology 7: 805-810.

Cecep Kusmana.2003. Jenis-jenis pohon mangrove di teluk bintuni, papua. Fakultas kehutanan institut pertanian bogor dan pt bintuni utama murni wood industries.3637.

Close, D.C. dan McArthur,C. 2002. Rethinking the role of many plant phenolics protection from photodamage not herbivores. 99: 166-172. 
Day, R.A. \& Underwood, A.L. 1999. Analisis Kimia Kuantitatif Edisi 6. Erlangga. Jakarta.

Fessenden, R.J, Fessenden, J.S. (1986), Organic Chemistry, 3th edition, Brooks/Cole Publishing Company, California

H.MJ. Lemmens dan N Wulijarni-Soetjipto (1999), Sumber Daya Nabati Asia Tenggara, No 3 "Tumbuhan Penghasil Pewarna dan Tanin", Balai Pustaka,Jakarta

Hagerman, A.E., C.T. Robbins, Y. Weerasuriya, T.C.Wilson, and C. McArthur. 1992. Tannin chemistry inrelation to digestion. Journal of Range Management 45(1): 57-62.

Harborne, J. 1987. Metode Fitokimia: Penuntun cara modern menganalisis tumbuhan. Translated by K. Padmawinata dan I. Soediro. Bandung: Institut Teknologi Bandung.

Harborne, J. B. 1996. Metode Fitokimia. Terbitan ke-II. a.b. Kosasih Padmawinata. Penerbit ITB. Bandung.

Horvath, P. J. (1981). The Nutrional and Eculogical Significance of Acer Tanins and Related Polyphenols. Thesis. New York: Cornell University.

Laksono, S. 2012. Pengolahan Biologis Limbah Batik Dengan Media Biofilter.

[Skripsi Ilmiah]. Depok: Fakultas Teknik Universitas Indonesia.

Malthaputri,E.R. 2007. Kajian aktivitas antimikroba ekstrak kulit kayu mesoyi Cryptocaria massoia terhadap bakteri pathogen dan pembusuk pangan. Skripsi. Bogor. Fakutas Teknologi Pertanian. Institut Pertanian Bogor.

Prabowo, A.Y, T. Estiasih, I. Purwatiningrum. 2014. bahan pangan mengandung senyawa bioaktif: kajian pustaka. Jurnal Pangan dan Agroindustri 2 (3):129135.

Rambe, M.A., 2009, Pemanfaatan Biji Kelor (Moringa oleifera) sebagai Koagulan Alternatif dalam Proses Penjernihan Limbah Cair Industri Tekstil, Tesis, Sekolah Pasca Sarjana, Universitas Sumatera Utara, Medan

Risnasari, I. 2002. Tanin. [Karya Tulis]. Departemen Kehutanan, Fakultas Pertanian, Universitas Sumatera Utara. Medan.

Susanto, Sewan. SK. 2002. Seni Kerajinan Batik Indonesia. Yogyakarta : Balai Penelitian Batik. 